\title{
Green Technological Progress and the Backwardness Advantage of Green Development: Taking the Sustainable Development Strategy of Central and Western China as an Example
}

\author{
Huaide Wen (1) and Jun Dai *
}

Citation: Wen, H.; Dai, J. Green Technological Progress and the Backwardness Advantage of Green Development: Taking the Sustainable Development Strategy of Central and Western China as an Example. Sustainability 2021, 13, 7567. https:// doi.org/10.3390/su13147567

Academic Editor: Cinzia Buratti

Received: 26 April 2021

Accepted: 2 July 2021

Published: 6 July 2021

Publisher's Note: MDPI stays neutral with regard to jurisdictional claims in published maps and institutional affiliations.

Copyright: (c) 2021 by the authors. Licensee MDPI, Basel, Switzerland. This article is an open access article distributed under the terms and conditions of the Creative Commons Attribution (CC BY) license (https:/ / creativecommons.org/licenses/by/ $4.0 /)$.
Qianjiang College, Hangzhou Normal University, Hangzhou 310018, China; wenhuaide@163.com

* Correspondence: daijun503@huqc.edu.cn

\begin{abstract}
It is generally believed that research and development on green technology are difficult, but this paper finds that the gap in green technological progress between the central and western regions and the eastern region in China is significantly smaller than the gap in technological progress, and the per capita green GDP of the central and western regions caught up with the eastern region significantly faster than the per capita GDP. This paper proposes that the comparative advantage of human capital level in the central and western regions is the reason why these regions choose the direction of green technological progress, and the choice of the direction of green technological progress in the central and western regions may further bring about the backwardness advantages of green development in these regions. Through the system generalized method of moments (sysGMM) estimation, empirical research using panel data from 29 provinces as well as the regional panel data in the mainland of China from 1995 to 2017 proved the above proposition. Specifically, due to the comparative advantages of human capital level, the central and western regions have chosen the direction of green technological progress; further, the central and western regions will obtain greater benefits of green GDP growth from the green technological progress, that is, the green technological progress enables these regions' backwardness to take advantage from green development. This is a useful supplement to the theory of sustainable development and the theory of backwardness advantage.
\end{abstract}

Keywords: green development; human capital level; green technological progress (GTP); backwardness advantage; comparative advantage

\section{Introduction}

Gerschenkron [1] put forward the theory of backwardness advantage that due to the diversity and selectivity of institutional arrangements, underdeveloped countries can be at a relatively high starting point from the very beginning by imitating technologies from developed countries, introducing equipment and funds, and drawing lessons from successful experiences. Therefore, underdeveloped countries will achieve faster economic growth driven by a strong desire for industrialization. Related to this, Abramovitz [2] proposed the "catch-up hypothesis", and Brezis and Krugman [3] proposed the "leapfrog model". In addition, based on Watson's "curse to the late comer", Yang [4] proposed the backwardness disadvantage of developing countries. This triggered a controversy regarding the two theories of backwardness advantage and backwardness disadvantage in China in the early 21st century, but it also made the theory of backwardness advantage receive widespread attention in China. Generally speaking, there is more literature supporting the theory of backwardness advantage. Guo [5] published a paper in Guangming Daily to point out that China will achieve economic development by leaps and bounds by leveraging its backwardness advantages. The theory of backwardness advantage has gradually become one of the policy bases for guiding China's economic growth. In the context of increasing environmental pollution in the world, many developing countries, 
including China, no longer regard economic growth as the only goal but pay more attention to green development. Therefore, this paper proposes that more attention should be paid to whether there is a backwardness advantage in green and sustainable development.

In recent years, the economy has grown fast in China, but regional development is extremely uneven. Compared with the developed eastern regions (hereinafter referred to as E-region), the central and western regions (hereinafter referred to as CW-regions) are considered to be the "catch-up" economy. At present, there is a large gap of the GDP and green GDP between the central and western regions and the eastern region in China. In 1995, the per capita GDP of the eastern, central, and western regions (1995 as the base year) grew on average by $8409.64,3701.55$, and 3197.10 RMB Yuan, respectively. By 2017, they reached 58,091.94, 30,825.91, and 26,345.55 RMB Yuan, respectively. The absolute gap has been widening. However, the mean growth rates of per capita GDP in the three regions were $9.36 \%, 10.16 \%$, and $9.99 \%$, respectively. The per capita GDP growth rates of the CW-regions were $0.8 \%$ and $0.63 \%$ faster than that of the E-region, that is, the CWregions have achieved relatively faster development. It is generally believed that green technology is more difficult to develop [6], so green development in the CW-regions may be difficult. However, we calculated the green GDP of the three regions (see Section 2 for specific methods) and found that although the absolute gap between the green GDP of the CW-regions and the E-region is relatively large, the mean growth rate of the per capita green GDP in the CW-regions is significantly higher than the E-region. In 1995, the per capita green GDP of the three regions (1995 as the base year) were 8147.39, 3,492.00, and 2968.95 RMB Yuan, respectively, and by 2017 they were 56,545.22, 29,475.74, and $24,628.81$ RMB Yuan, respectively. The per capita green GDP in the three regions grew on average by $9.37 \%, 10.22 \%$, and $10.04 \%$, respectively. The per capita GDP growth rates in the CW-regions were $0.85 \%$ and $0.67 \%$ faster than those in the E-region, which shows that the per capita green GDP of the CW-regions is catching up with the E-region at a significantly faster rate than the per capita GDP. Previous research has focused more on exploring the backwardness advantage of the traditional economy while ignoring the backwardness advantage of green GDP. However, the above data shows that the CW-regions are more likely to have a backwardness advantage of green development.

We found that the relative gaps between the CW-regions and the E-region in terms of financial capital, labor employment, and technological progress rates are all widening (see Appendix A for details). However, China has implemented preferential education policies in the CW-regions, which has enabled faster development of human capital in these regions. In recent years, human capital has accumulated rapidly in China. By 2017, the total enrollment of higher education has been close to thirty-seven million, accounting for more than fifth part of the total scale of higher education in the world. In terms of different regions, the average growth rates of education expenditure per student in the CW-regions from 1995 to 2017 were 12.42\% and 13.53\%, respectively, which was higher than the $12.05 \%$ in the E-region, and the average growth rates of the population with at least higher education accounted for the population aged 6 and over were 14.01\% and $11.35 \%$, respectively, which are also significantly higher than $10.50 \%$ in the E-region. If the level of education represents the level of human capital, the absolute gap in the human capital level between the three regions will continue to narrow. From a dynamic perspective, due to the faster increasing rate of human capital level in the CW-regions, human capital in these regions has gradually become a new comparative advantage (i.e., a smaller absolute disadvantage).

Our earlier research [6] proposed that the relatively faster accumulation of human capital will prompt a country to choose the direction of green technological progress (hereinafter referred to as GTP) based on Acemoglu [7], and later research [8] using the spatial Dubin model proved that human capital level is beneficial to the GTP in China. Referring to Chung et al. [9], Jing and Zhang [10], and Ma et al. [6], the authors calculated the rate of GTP in the three regions in China (see Section 2 for specific methods) and found that from 1995 to 2017, the average rate of GTP in the E-region was ahead of the 
$\mathrm{CW}$-regions, less than the leading rate of average technological progress at $6.07 \%$ and $7.18 \%$, respectively. This indicates that the CW-regions may indeed have developed more GTP. Based upon this, this study puts forward that the comparative advantages of human capital in the CW-regions may prompt these regions to choose GTP more, which may be the reason why the green GDP of the CW-regions has developed faster.

Sustainable development strategy and digital economy strategy widely implemented in the CW-regions may support the above statement. Sichuan Province focuses on the development of the digital economy and now Chengdu, the capital of Sichuan Province, has become a major digital economy center in China, with an output value of 2 trillion RMB Yuan in the digital economy in 2020. Guizhou Province focuses on the development of the big data industry and has gradually grown to a data center in China. The electronic information industry vigorously developed in Chongqing has become the main driving force for local economic growth. Provinces of Hubei, Hunan, Henan, Anhui, Jiangxi, Guangxi, Yunnan, and Shaanxi also take the digital economy and green manufacturing as their economic development priorities, and the output value of digital economy in provinces of Hubei, Hunan, Henan, and Anhui exceeds 1 trillion RMB Yuan. The digital economy of Chongqing, Hubei, Guangxi, Sichuan, Jiangxi, and Guizhou, etc., accounted for more than $30 \%$ of GDP. As these green industries have stronger competitiveness and bring higher profits, the CW-regions may have gained a backwardness advantage in green development.

The following literatures provide the basis for this paper, although it does not directly involve the backwardness advantage of green development.

Current research generally believes that technological progress is the key factor for underdeveloped countries and regions to gain a backwardness advantage $[1,11,12]$. Gerschenkron [1] believes that underdeveloped countries will benefit from technological and economic imitation, and the higher their degree of backwardness, the faster their growth rate and convergence with developed countries. Research demonstrated that underdeveloped countries have achieved faster economic growth in the context of international technology spillovers $[2,11,13]$. Lin and Zhang [14] proposed that underdeveloped countries could achieve technological catch-up and endogenous growth by leveraging their backwardness advantages. Landesmann and Stehrer [15] believe that the comparative advantages of underdeveloped economies can be increasingly shifted to medium and high-tech sectors to achieve rapid growth. Lin [12] believes that China has a backwardness advantage in pursuing technological innovation and structural transformation. Utkuİsmihan [16] shows that communication and information technology play an important role in the economic growth in the underdeveloped regions of Middle East, etc., and there exists economic convergence among countries in these regions. Vu and Asongu [17] discussed the backwardness advantage of developing countries in the information era and found that compared with the average developed countries, developing countries have gained more benefits from Internet applications. Gosens et al. [18] showed that the formative nature of the Solar Power sector resulted in turbulent development of the technological, market, and institutional dimensions, making it more difficult for early leaders to retain leadership and therefore easier for latecomer firms or countries to catch up. Chen et al. [19] proposed to promote market-oriented construction and improve the level of economic organization in the western region of China, which can also promote economic catch-up in these regions.

However, some researchers have also realized that achieving backwardness advantage through technological progress is not easy. Fagerberg [20] believes that the potential for "catching up" (imitation) exists, but it is not easy to catch up through technology. It requires underdeveloped countries to have strong social capabilities to mobilize the essential resources. Forbes and Wield [21] believe that when the follower country acquires and uses existing technology, the leading country has moved towards a new technological frontier. Harada [22] proposed that backwardness advantage might circulate in low-tech sectors, so it was difficult to obtain backwardness advantage. Zabala-Iturriagagoitia et al. [23] 
believe that innovation activities do not necessarily imply technological improvements, and innovation activities do not prompt follower and lagging countries to catch up with more advanced ones. In addition, some researchers have shown that backwardness advantages in certain industries may be difficult to achieve. Rho et al. [24] explained the reasons for limited catch-up first in terms of the characteristics of the technology/knowledge regime of the industry where innovations are frequent and technologies are highly cumulative, which put a latecomer in a disadvantageous position. Minaee et al. [25] found that the sectoral environment of Iran's automobile industry was characterized by ineffective technology transfer, diverse technological areas, high tacit knowledge, etc., which contributes to the lackluster performance of catching-up by the domestic firm.

The impact of green technologies (including energy-related technologies and new energy technologies) on green development has also attracted the attention of researchers. Most research holds that green technologies are an important means of energy-saving and emission-reduction. Scholars believe that energy technology progress is beneficial to energy saving and carbon emission reduction [26,27]. The International Energy Agency [28] proposed that among various approaches to mitigating climate change, green technologies are expected to become the dominant factors, which theoretically contribute to the goal of reducing more than $60 \% \mathrm{CO}_{2}$. However, in different nations and areas, the influence of green technological innovation varies due to the specific conditions of $R \& D$ and promotion for green technologies [29]. Literature has successively concluded that technological advancement in energy and environment fields could reduce the $\mathrm{CO}_{2}$ emissions [30-33]. Researchers proposed that green technology innovation has become an important means of reducing $\mathrm{CO}_{2}$ emissions globally [34-36]. Gu et al. [37] believe that patents on renewable energy technologies and patents on energy saving and emission reduction technologies will reduce carbon emissions. Paramati et al. [38] adopted robust panel estimation technology, taking the annual data of 25 OECD countries as the sample, and deduced that green technology reduced carbon emissions.

Although some other studies also acknowledge the role of GTP in reducing carbon emissions, they believe that under certain conditions, it may not be able to reduce carbon emissions. Researchers found that patents of energy technology were not significant to $\mathrm{CO}_{2}$ emissions reduction in China, and the energy patents using free carbon technology only beneficial to $\mathrm{CO}_{2}$ emissions reduction in eastern China [39]. Braungardt et al. [40] believe that although green innovation is regarded as a basic element of a green growth strategy, its influence on climate has been debated for a long time because of the rebound effects. Weina et al. [35] revealed that for Italy, green innovation has improved environmental productivity, but it has failed to play an important role in reducing $\mathrm{CO}_{2}$ emissions. Su and Moaniba [36] believe that although climate-related technologies are theoretically beneficial to coping with climate change, the empirical evidence is insufficient. Popp [41] pointed out that the use of green technologies often requires initial costs, which makes it impossible for poor economies to use advanced technologies of emission reduction and achieve environmental goals. Acemoglu et al. [42] believe that the impact of green technology innovation on carbon emissions may be uncertain due to different reasons. Du et al. [43] took 71 economies as the sample and found that green technological innovation did not have significant emission reduction effects for economies with a lower income than the threshold, but for economies with higher income than the threshold, the emissions reduction effect becomes important.

The above research shows that although there is controversy, it is generally believed that technological progress is the key factor for developing countries to achieve backwardness advantages and that green technologies are of great significance to environmental protection and green development. There is no relevant study at present on the backwardness advantage of green development in developing countries. However, the above two types of research provide the idea for this paper, that is, the GTP may bring about the backwardness advantage of green development in developing countries. This paper takes the $\mathrm{CW}$-regions of China as catch-up economies and explores the possibility of backwardness advantage of green development in these regions. This is a new work. It will provide a 
policy basis for the further development of the green economy in China's CW-regions, and it will also be a reference for some countries with obvious regional economic imbalances and severe environmental conditions like China.

Section 2 in this paper analyzes the mechanism of GTP on the backwardness advantage of green development and puts forward the measurement model and test method. Section 3 takes empirical research to get the results and discussion. Section 4 gives policy recommendations based on the research conclusions.

\section{Materials and Methods}

\subsection{Theoretical Analysis}

This paper focuses on the backwardness advantage of green development caused by GTP. Referring to the theoretical models of Copeland and Taylor [44], Wen and Dai [45] on changes in production factors and improvement of environmental quality, this paper assumes that a country has two kinds of industries. The one is a polluting industry indicated by $X$, which produces product $x$ and pollutants. Its production mainly uses gray technology $T$. The other is a clean industry denoted by $Z$, which produces clean products and mainly uses green technology G. Using Rybzinski's theorem [46] (although Rybzinski's theorem generally addresses production factors such as capital, labor, and human capital, this paper believes that it is equally applicable to technology. Because if a region adopts more green technologies, the corresponding resources will be more concentrated in the green industry, which will promote the growth of the output of the green industry. Correspondingly, the gray industries in the region can only have fewer resources and output. Similarly, if more gray technologies are adopted, the output of gray industries will increase while the output of green industries will decrease), we can infer the economic and environmental changes brought about by the different growth rates of the two kinds of technologies.

According to the theoretical model of Copeland and Taylor [44] and Wen and Dai [45], the pollution emission function is expressed as

$$
P=\bar{e} x\left(\bar{\tau}, T_{x}, G_{x}\right)
$$

Here, $P$ refers to environmental pollution, which is determined endogenously by Equation (1). $\tau$ is the tax for pollution discharge (or the price enterprises pay for pollution discharge). $e$ is the pollution discharge intensity. To analyze the influence of changes in gray technology and clean technology on pollution, the tax for pollution discharge is set unchanged as $\tau=\bar{\tau}$, and the pollution discharge intensity is assumed unchanged as $e=\bar{e}$.

The income equation can be correspondingly concisely written as

$$
Y=f(T, G, P)
$$

Here, $Y$ refers to the output. When the economic growth is mainly promoted by the progress of gray technology $T$, keep $G$ unchanged, and take the logarithm of formulas (1) and (2) and then differentiate, we can get:

$$
\begin{gathered}
\hat{P}=\varepsilon_{X T} \hat{T} \\
\hat{Y}=s_{r} \hat{T}+s_{\tau} \hat{P}
\end{gathered}
$$

$\hat{P}=d \ln (P)=d P / P$, and so on. $\varepsilon_{X T}$ denotes the elasticity of the output of polluting industry $X$ relative to gray technology. According to Rybzinski's theorem [46], when the quantity of one production factor increases while the quantity of another production factor remains unchanged, the result is that the products produced by intensive use of the former will increase, while the products produced by intensive use of the latter will decrease. Polluting industry $X$ uses gray technology intensively. As it is assumed that gray technology advances while green technology remains unchanged, product $x$ will increase, while industry $Z$, which mainly uses green technology, will produce fewer products; then, 
there is $\varepsilon_{X T}>0 . s_{r}$ and $s_{\tau}$ respectively denote the ratio of income of gray technology and tax for pollution emission in output. $s_{r}>0 . s_{\tau}>0$. Substitute formula (3) into (4), we have

$$
\hat{Y}=\left(s_{r}+s_{\tau} \varepsilon_{X T}\right) \hat{T}
$$

Since it has been assumed that there is gray technology progress, namely, $\hat{T}>0$, we have $\hat{P}>0$ according to formula (3) and $\hat{Y}>0$ according to formula (5). This means that progress in gray technology has increased pollution levels and income simultaneously, but the output growth here is mainly gray, while green output is declining. Therefore, the green GDP growth rate after deducting the resources and environmental losses of gray output will decline relative to the growth rate of GDP.

In the same way, it is assumed that the economy is mainly promoted by the GTP, denoted by $G$ and keeping $T$ unchanged, then

$$
\hat{P}=\varepsilon_{X G} \hat{G}
$$

$\varepsilon_{X G}$ refers to the elasticity of the output of polluting industry $X$ relative to green technology. It is still based on Rybzinski's theorem; the output of clean industry $Z$ is stimulated by the GTP, and the available resources of pollution industry $X$ decrease, so there must be $\varepsilon_{X G}<0$. Furthermore, it can be seen from formula (6) that GTP has reduced the level of pollution emissions. The impact of GTP on income is

$$
\hat{Y}=s_{w} \hat{G}+s_{\tau} \hat{P}=\left(s_{w}+s_{\tau} \varepsilon_{X G}\right) \hat{G}
$$

$s_{w}>0$, which denotes the ratio of green technology income in national income. Since it is assumed that there exists GTP, namely, $\hat{G}>0$. Because of $\varepsilon_{X G}<0, \hat{P}<0$ according to formula (6). Since $s_{\tau}>0$ and $\varepsilon_{X G}<0$, there is $s_{\tau} \varepsilon_{X G}<0$, and the economic growth here is mainly promoted by the GTP; $s_{w}$ is greater, and the absolute value of the product of $s_{\tau}$ and $\varepsilon_{X G}$ should be small, namely, $s_{w}>\left|s_{w} \varepsilon_{X G}\right|$. For $\hat{G}>0$, then $\hat{Y}>0$. In other words, relying mainly on the GTP while keeping the gray technology constant will increase the whole national income, which is consistent with the general knowledge. (It should be noted that if economic growth is mainly promoted by GTP but the proportion of green technology income in national income is not large enough, it may lead to $\hat{G}<0$, that is, a decline in economic growth. The reason for this situation may be insufficient progress in green technology and low marginal output. It means that the phase growth rate of the economic growth with green technological progress as the main driving force may decline. This paper does not consider this situation.) Thus formulas (6) and (7) mean that the human capital level increases while income is increased, but pollution is reduced. The output growth here is mainly the green output growth, while the gray output is declining. Therefore, the green GDP growth rate after deducting the resources and environmental losses of gray output will increase, relative to the GDP growth rate.

To sum up, if a country mainly relies on gray technology progress to promote economic growth, environmental pollution and income increase, but the growth rate of green GDP declines relative to GDP growth rate, and if it mainly relies on GTP to promote economic growth, as green output grows, environmental pollution will decrease, so green GDP will grow faster relative to GDP growth. Therefore, if a country or region chooses the direction of GTP more, it will achieve faster green development. Developed countries or regions have path dependence on gray technology to a certain extent [47], and they are directly facing the frontier of green technology, so there are difficulties in research and development. However, developing countries with certain human capital conditions will achieve GTP relatively easily through introduction and imitation. Therefore, for developing countries, if they choose the direction of GTP more, it may mean that they will gain the backwardness advantage of green development.

Since the authors have proposed and verified that human capital accumulation promoted GTP [8] and pointed out in the introduction that the CW-regions had comparative 
advantages in human capital, this paper further proposes proposition 1: the comparative advantage of human capital in the CW-regions of China has prompted these regions to choose GTP more. If the CW-regions choose GTP more between the two technologies, according to the above analysis in this section, we can further put forward proposition 2: the $\mathrm{CW}$-regions of China will gain the backwardness advantage of green development for choosing GTP more. If the above assumptions are confirmed, it will be of great significance for alleviating the contradiction between economic catch-up and environmental protection for underdeveloped regions in China, and it will also have important significance for the economic transformation and sustainable development of other developing countries. This paper uses sys-GMM estimation and panel data from 29 provinces as well as regional panel data in China from 1995 to 2017 to conduct an empirical test. This research will further enrich the theory of sustainable development and the theory of backwardness advantage, which is a new work.

\subsection{Empirical Model and Variables}

First, this research tests the influence of human capital level on GTP. Based on the empirical research on GTP [10], the following model is set up:

$$
G T P_{i t}=\alpha_{0}+\alpha_{1} H_{i t}+\alpha_{2} \ln E_{i t}+\alpha_{3} \ln E^{2}{ }_{i t}+X_{i t}^{\prime} B+f_{i}+f_{t}+e_{i t}
$$

where GTP is the green technological progress, and $H$ is the human capital level. Considering the possible U-shaped impact of environmental regulations on the GTP in Porter Hypothesis [10,48], we set environmental regulation variables $E$ and $E^{2}$ in the model. $f_{i}$ and $f_{t}$ are the non-observed regional fixed effect and time fixed effect respectively, and $e_{i t}$ refers to the error term. Control variable $X^{\prime}$ includes material capital $K$, foreign direct investment $F D I$, R\&D expenditure $R D$, labor force $L$, trade openness $T r$, and environmental pollution $P$. Considering the important impact of trade openness on environmental regulation in "running to the bottom" hypothesis and the "pollution paradise" hypothesis, this paper sets up the cross-term $\ln T{ }^{*} \ln E$ of trade openness and environmental regulation to test the influence of environmental regulation on GTP under trade opening. Regarding the variable of environmental pollution $P$, this paper takes carbon dioxide emissions, the most representative pollutant, as the environmental pollution indicator, denoted as $P_{-} \mathrm{CO}_{2}$. Due to the numerous environmental pollution indicators, we add the chemical aerobic emission, representative pollutant indicators of wastewater, denoted as $P_{-} C O D$, and the comprehensive loss of environmental pollution, indicated by $P \_p u l$, for robustness test.

Secondly, to test the backwardness advantage effect of green development from GTP, we set up the following dynamic model referring to Eicher and Schreiber [49], Vu and Asongu [17] to verify the backwardness advantage:

$\ln G G D P_{i t}=\alpha_{0}+\alpha_{1} \ln G G D P_{i t-1}+\alpha_{2} \ln W_{i t-1}+\alpha_{3} \ln G T P_{i t-1}+\alpha_{4} \ln G T P_{i t-1} *$ Backward $_{i}+X^{\prime \prime}{ }_{i t} B+f_{i}+f_{t}+e_{i t}$

where GGDP is the per capita green GDP. $W$ is the income level of residents to control the conditional convergence effect. $G G D P_{i t-1}, W_{i t-1}$ and $G T P_{i t-1}$ are the initial levels of the variables in each period. The interactive variable $G T P_{i t-1} *$ Backward $_{i}$ is used to test whether different regions will obtain huge green growth benefits from GTP, where Backward $_{i}$ is a dummy variable. If the region is defined as an underdeveloped region, it is equal to 1 , otherwise, it is equal to 0 . The central region is set as Backward ${ }_{i-}$ mid, and the

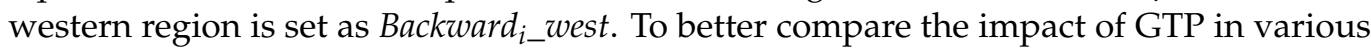
regions on green GDP, the E-region is set as east. $X^{\prime \prime}$ indicates the control variables affecting the growth of green GDP including human capital $H$, physical capital $K$, labor force $L$, and environmental regulation $E$. Variable description see Table 1. 
Table 1. Variable description.

Variables Symbol

The method of Tan and Wen [50] is used to estimate the environmental pollution losses including main pollutants in China based on 1995. The various resource consumption losses in China based on 1995 are estimated referring to Wen [51]. Green GDP is calculated by gross regional product subtracting environmental pollution losses and resource consumption losses based on 1995. Then per capita green GDP is calculated by dividing the green GDP by the permanent population of each province.

GTP is measured by green total factor productivity according to Jing and Zhang [10] (Jing and Zhang [10] pointed out that many studies decomposed total factor productivity into technological changes and efficiency changes, but they believe that technological progress should be measured by the sum of the two. The reason is that on the one hand, technological change actually measures the total factor productivity chan at the frontier productivity chan productivity change at the sample frontier, and it is not reasonable to measure technological progress by the frontier productivity change on the other hand, the change in efficiency reflects the absorbing ability to current technological knowledge, which is also a manifestation of technological progress. Reflecting technological progress as the continuous process of each decision-making unit's pursuit of global frontier technologies is a more reasonable measurement), using the method of Chung et al. [9] to calculate the ML index of green total factor productivity. The input variables are capital stock, employees, and energy consumption. The output variables include the expected output of the gross regional product based on 1995 and the undesired output of $\mathrm{CO}_{2}$ emissions, $\mathrm{COD}$ emissions, and $\mathrm{SO}_{2}$ emissions. Finally, the cumulative multiplication method of Yuan [52] is used to obtain GTP.

\begin{tabular}{|c|c|c|}
\hline Human capital level & $H$ & The human capital level is estimated by the average years of education referring to Ma et al. [6]. \\
\hline Environmental regulation & E & $\begin{array}{l}\text { GDP/energy consumption is set as a proxy variable for environmental regulation referring to Ma et al. [6] and Wen and Dai [53]. Energy } \\
\text { consumption is converted into standard coal, and then, the GDP of each province based on } 1995 \text { is divided by the energy input. }\end{array}$ \\
\hline Trade openness & $\operatorname{Tr}$ & $\begin{array}{l}\text { It is indicated by total import and export volume, which is adjusted to the constant price in } 1995 \text { by the United States CPI and then } \\
\text { converted into RMB yuan based on the average exchange rate in } 1995 .\end{array}$ \\
\hline R\&D investment & $R D$ & $\begin{array}{l}\text { It is estimated by the perpetual inventory method of Li et al. [54], taking R\&D stock in } 1995 \text { as the initial amount, with a depreciation rate } \\
\text { of } 15 \% \text {. The newly added R\&D is converted to the constant price in } 1995 \text { based on the average CPI and PPI. }\end{array}$ \\
\hline Environmental pollution 1: $\mathrm{CO}_{2}$ & $\mathrm{P}_{-} \mathrm{CO}_{2}$ & The carbon dioxide emission is estimated by the consumption of coal, oil, and natural gas referring to Chen [55]. \\
\hline Environmental pollution 2: COD & P_COD & It is the emissions of chemical oxygen demand of each province. \\
\hline $\begin{array}{l}\text { Environmental pollution 3: Comprehensive loss of } \\
\text { environmental pollution }\end{array}$ & P_pul & $\begin{array}{l}\text { The comprehensive loss of environmental pollution is calculated by the emission of major pollutants referring to Tan and Wen [47], and } \\
\text { Wen and Dai [45] and converted to the constant price in } 1995 \text { by PPI. }\end{array}$ \\
\hline Resident income level & W & The average wage of urban employees in each province in the current year is selected and converted into the constant price in 1995. \\
\hline Physical capital & $K$ & $\begin{array}{l}\text { It is calculated based on the method of Zhang [56] and Wen and Dai [45], in which the investment price index is measured by the fixed } \\
\text { assets investment price index based on } 1995 .\end{array}$ \\
\hline Foreign direct investment & FDI & $\begin{array}{l}\text { FDI stock is calculated by the above formula of Zhang [56], with the FDI stock in } 1995 \text { as the initial volume and the depreciation rate } \\
\text { selected at } 7.5 \% \text {. The newly added FDI is converted to RMB yuan at the annual average exchange rate in 1995, and the price index is } \\
\text { based on the United States CPI. }\end{array}$ \\
\hline
\end{tabular}


Due to the data availability of some variables, the sample ranges from 1995 to 2017. Unless otherwise specified, the data in this paper are taken from the relevant statistical yearbooks of the National Bureau of Statistics and the relevant statistical yearbooks of various provinces and regions. The descriptive statistics of the variables are shown in Table 2.

Table 2. Descriptive statistics of the variables.

\begin{tabular}{|c|c|c|c|c|c|c|}
\hline Variables & Mean Value & Median Value & $\begin{array}{c}\text { Standard } \\
\text { Deviation }\end{array}$ & $\begin{array}{c}\text { Minimum } \\
\text { Value }\end{array}$ & $\begin{array}{c}\text { Maximum } \\
\text { Value }\end{array}$ & $\begin{array}{c}\text { Number of } \\
\text { Observations }\end{array}$ \\
\hline $\ln G G D P_{i t}$ & 9.380 & 9.392 & 0.873 & 7.000 & 11.449 & 667 \\
\hline$G T P_{i t}$ & 4.232 & 2.460 & 4.963 & 0.892 & 73.86 & 667 \\
\hline$H_{i t}$ & 2.090 & 2.101 & 0.149 & 1.546 & 2.526 & 667 \\
\hline $\ln E_{i t}$ & 8.735 & 8.780 & 0.538 & 7.400 & 9.793 & 667 \\
\hline $\operatorname{Tr}_{i t}$ & 6.756 & 6.720 & 1.817 & 2.109 & 10.99 & 667 \\
\hline $\ln F D I_{i t}$ & 6.017 & 6.149 & 1.727 & -3.042 & 9.098 & 667 \\
\hline $\ln R D_{i t}$ & -0.148 & -0.140 & 0.874 & -3.760 & 2.130 & 667 \\
\hline $\ln P_{-} C_{2 i t}$ & 9.697 & 9.760 & 0.924 & 6.430 & 11.650 & 667 \\
\hline $\ln P_{-} C O D_{i t}$ & 3.675 & 3.770 & 0.817 & 1.160 & 5.290 & 667 \\
\hline $\ln \bar{P} \_p u l_{i t}$ & 5.271 & 5.354 & 1.010 & 1.744 & 7.412 & 667 \\
\hline $\ln W_{i t}$ & 9.670 & 9.727 & 0.739 & 8.327 & 11.26 & 667 \\
\hline $\ln K_{i t}$ & 9.470 & 9.447 & 1.124 & 6.354 & 11.97 & 667 \\
\hline $\ln L_{i t}$ & 7.525 & 7.634 & 0.839 & 5.483 & 8.820 & 667 \\
\hline
\end{tabular}

\subsection{Estimation Method}

Following the previous research [57-59], to solve the potential endogenous problems of the model and the problem of weak instrumental variables, this paper intends to use the two-step Sys-GMM estimation. In addition, the applicability of the two-step sys-GMM can be interpreted as follows. First, the province $n=29$ is greater than the year $t=23$, which meets the basic demands of the two steps sys-GMM. Second, the explained variable is continuous. The correlation coefficients of green GDP, GTP, and their first-order lag are 0.999 and 0.904 , respectively, which are higher than the empirical threshold of 0.800 required to establish sustainability. Third, the GMM technology using the panel data structure will not eliminate inter-provincial changes. Fourth, the estimation method takes into account the simultaneity of explanatory variables as well as endogeneity, that is, the simultaneity of explanatory variables is calculated through the instrumental variable process, and the unobserved heterogeneity is controlled by time-invariant indicators. Fifth, sys-GMM corrects the unobserved heteroscedasticity problem, and the two-step sys-GMM is selected because it controls the heteroscedasticity, while the one-step method only controls the homoscedasticity [60].

This paper also considers the possible multicollinearity. Chen [61] believes that if multicollinearity affects the significance of the key variables, we should try to modify the model. Otherwise, no additional processing is required. If there is no multicollinearity, the coefficients of variables will only be more significant. First, this paper uses stata14 for panel data estimation, and strict collinearity variables will be automatically eliminated by Stata [61]. Second, by calculation of the variance inflation factor (VIF) between the independent variables of formula (8), it is found that the VIFs of $\ln E, \ln E^{2}$, and $\ln \operatorname{Tr}^{*} \ln E$ under the three explanatory variables of environmental pollution all exceed 1000, which leads to the huge average VIF of the model, so the first judgment is that there exists serious Multicollinearity. However, the settings of the above variables have a theoretical basis, and the main variables of the model are all significant in Tables 3 and 4 with expected signs of the coefficients of the variables, so this paper does not deal with this. As Woodridge [62] proposed, to eliminate multicollinearity, some variables can be removed, but it may lead to model bias, so the too large VIF does not affect our decision. By the calculation of the VIF of all the independent variables in formula (9), it shows that when four variables GTP $P_{i t-1}$, $G T P_{i t-1} *$ east, GTP $P_{i t-1} *$ Backward $_{i-}$ mid and GTP $P_{i t-1} *$ Backward $_{i-}$ west are put into the 
model simultaneously, the average VIF reaches more than 10,000 , and the four variables are not significant, indicating that the multicollinearity has severely affected the test of the model. Therefore, this paper abandons this model setting and sets three measurement models based on formula (9), considering model (10) only GTP $P_{i t-1}$ included, model (11) excluding $G T P_{i t-1} *$ east and model (12) excluding $G T P_{i t-1}$ as follows:

$$
\begin{gathered}
\ln G G D P_{i t}=\alpha_{0}+\alpha_{1} \ln G G D P_{i t-1}+\alpha_{2} \ln W_{i t-1}+\alpha_{3} \ln G T P_{i t-1}+X^{\prime \prime}{ }_{i t} B+f_{i}+f_{t}+e_{i t} \\
\ln G G D P_{i t}=\alpha_{0}+\alpha_{1} \ln G G D P_{i t-1}+\alpha_{2} \ln W_{i t-1}+\alpha_{3} \ln G T P_{i t-1}+\alpha_{4} \ln G T P_{i t-1} * \text { Backward }_{i \_} \text {mid } \\
+\alpha_{5} \ln G T P_{i t-1} * \text { Backward }_{i \_} w e s t+X^{\prime \prime}{ }_{i t} B+f_{i}+f_{t}+e_{i t} \\
\ln G G D P_{i t}=\alpha_{0}+\alpha_{1} \ln G G D P_{i t-1}+\alpha_{2} \ln W_{i t-1}+\alpha_{3} \ln G T P_{i t-1} * e a s t+\alpha_{4} \ln G T P_{i t-1} * \text { Backward }_{i-m i d} \text { mid } \\
+\alpha_{4} \ln G T P_{i t-1} * \text { Backward }_{i-w e s t}+X^{\prime \prime}{ }_{i t} B+f_{i}+f_{t}+e_{i t}
\end{gathered}
$$

\begin{tabular}{|c|c|c|c|}
\hline Variables & $\begin{array}{c}\text { Environmental Pollution } \\
\text { of } P_{-} C O D\end{array}$ & $\begin{array}{c}\text { Environmental Pollution } \\
\text { of } \mathrm{P}_{-} \mathrm{CO}_{2}\end{array}$ & $\begin{array}{c}\text { Environmental Pollution } \\
\text { of } P_{\_} p u l\end{array}$ \\
\hline $\ln H_{i t}$ & $\begin{array}{l}7.1198^{* * *} \\
(4.41)\end{array}$ & $\begin{array}{l}3.2034^{* * *} \\
(3.34)\end{array}$ & $\begin{array}{r}2.4522 \\
(1.47)\end{array}$ \\
\hline $\ln E_{i t}$ & $\begin{array}{l}-219.5220 * * * \\
(-8.31)\end{array}$ & $\begin{array}{l}-159.8766^{* * *} \\
(-13.65)\end{array}$ & $\begin{array}{c}-97.4303^{* * *} \\
(-3.36)\end{array}$ \\
\hline $\ln E_{i t}^{2}$ & $\begin{array}{l}12.7615^{* * *} \\
(7.98)\end{array}$ & $\begin{array}{c}8.9435^{* * *} \\
(11.51)\end{array}$ & $\begin{array}{c}5.4235^{* * *} \\
(3.04)\end{array}$ \\
\hline $\ln T r_{i t}$ & $\begin{array}{l}-4.1314 \\
(-1.32)\end{array}$ & $\begin{array}{l}-19.0594^{* * *} \\
(-4.73)\end{array}$ & $\begin{array}{l}-17.5104^{* * *} \\
(-3.58)\end{array}$ \\
\hline $\ln T r_{i t}{ }^{*} \ln E_{i t}$ & $\begin{array}{l}0.3079 \\
(0.88)\end{array}$ & $\begin{array}{l}1.9553^{* * *} \\
(4.33)\end{array}$ & $\begin{array}{l}1.7456^{* * *} \\
(3.26)\end{array}$ \\
\hline $\ln F D I_{i t}$ & $\begin{array}{l}0.6045 \\
(1.44)\end{array}$ & $\begin{array}{c}-0.5754 * \\
(-1.78)\end{array}$ & $\begin{array}{l}0.1294 \\
(0.26)\end{array}$ \\
\hline $\ln R D_{i t}$ & $\begin{array}{l}2.7703^{* * *} \\
\quad(9.41)\end{array}$ & $\begin{array}{l}2.1359 * * * \\
(6.23)\end{array}$ & $\begin{array}{c}0.4776 * \\
(1.69)\end{array}$ \\
\hline $\ln P_{i t}$ & $\begin{array}{l}1.5386^{* * *} \\
(4.16)\end{array}$ & $\begin{array}{l}3.3220^{* * *} \\
(7.08)\end{array}$ & $\begin{array}{l}4.2610^{* * *} \\
(11.70)\end{array}$ \\
\hline Constant & $\begin{array}{c}930.1656^{* * *} \\
(8.61)\end{array}$ & $\begin{array}{c}692.6568^{* * *} \\
(15.33)\end{array}$ & $\begin{array}{c}424.8056^{* * *} \\
(3.56)\end{array}$ \\
\hline Wald test & $714.17(0.000)$ & $1225.33(0.000)$ & $574.72(0.000)$ \\
\hline $\mathrm{AR}(2)$ test & $1.41(0.158)$ & $1.38(0.169)$ & $1.61(0.107)$ \\
\hline Hansen test & $27.07(0.301)$ & $25.30(0.711)$ & $21.34(0.126)$ \\
\hline $\begin{array}{l}\text { DHT for instruments (a) GMM } \\
\text { instruments for levels H excluding } \\
\text { group Dif (null } \mathrm{H}=\text { exogenous) }\end{array}$ & $0.51(0.972)$ & $1.67(0.893)$ & $1.63(0.898)$ \\
\hline $\begin{array}{l}\text { (b) IV (Years, eq (diff)) H excluding } \\
\text { group Dif (null } \mathrm{H}=\text { exogenus) }\end{array}$ & $4.38(0.356)$ & $2.07(0.556)$ & $0.18(0.981)$ \\
\hline Number of Instruments & 33 & 39 & 24 \\
\hline Number of Provinces & 29 & 29 & 29 \\
\hline obs & 609 & 580 & 580 \\
\hline
\end{tabular}

Table 3. Sys-GMM estimation results with GTP as the dependent variable.

Note: ${ }^{* * *},{ }^{*}$ represent the significance level of $1 \%$ and $10 \%$ respectively. The coefficients in parentheses of variables and constant terms are $z$ values. The coefficients in parentheses of the Wald test, Hansen test, and AR(2) test are $p$ values.

The above three models have met the needs of our research in this paper. The average VIFs of the three models are 5.01, 4.77, and 4.87, respectively, so it is judged that serious multicollinearity does not exist in the above models. 
Table 4. Regional sys-GMM estimation results with GTP as the dependent variable.

\begin{tabular}{|c|c|c|c|}
\hline Variables & The Eastern Region & The Central Region & The Western Region \\
\hline $\ln H_{i t}$ & $\begin{array}{l}25.8061^{* * *} \\
(3.50)\end{array}$ & $\begin{array}{l}26.2688^{* * *} \\
(2.71)\end{array}$ & $\begin{array}{l}26.1148^{* * *} \\
(2.77)\end{array}$ \\
\hline $\ln E_{i t}$ & $\begin{array}{c}-604.0252 * * \\
(-2.28)\end{array}$ & $\begin{array}{l}-191.6102 * * * \\
(-2.87)\end{array}$ & $\begin{array}{c}-76.7075 \\
(-1.08)\end{array}$ \\
\hline $\ln E_{i t}^{2}$ & $\begin{array}{c}33.7569 * * \\
(2.30)\end{array}$ & $\begin{array}{c}11.2762^{* * * *} \\
(2.97)\end{array}$ & $\begin{array}{l}4.6435 \\
(1.09)\end{array}$ \\
\hline $\ln T r_{i t}$ & $\begin{array}{c}-6.3235^{*} \\
(-1.83)\end{array}$ & $\begin{array}{l}-22.1718 \\
(-0.73)\end{array}$ & $\begin{array}{c}-20.5646^{*} \\
(-1.88)\end{array}$ \\
\hline $\ln T r_{i t}{ }^{*} \ln E_{i t}$ & $\begin{array}{c}0.9258^{*} \\
(1.88)\end{array}$ & $\begin{array}{c}3.0526 \\
(1.37)\end{array}$ & $\begin{array}{c}2.7891 * \\
(1.76)\end{array}$ \\
\hline $\ln F D I_{i t}$ & $\begin{array}{c}-1.8942 * * \\
(2.34)\end{array}$ & $\begin{array}{l}-1.3688 \\
(-1.58)\end{array}$ & $\begin{array}{l}0.3844 \\
(0.77)\end{array}$ \\
\hline $\ln R D_{i t}$ & $\begin{array}{c}5.3393 \\
(1.49)\end{array}$ & $\begin{array}{c}3.5911 \\
(1.12)\end{array}$ & $\begin{array}{l}1.4912^{* *} \\
(2.29)\end{array}$ \\
\hline $\ln P_{-} C_{2}$ it & $\begin{array}{c}2.0068 \\
(0.86)\end{array}$ & $\begin{array}{l}5.6610^{* * * *} \\
(4.02)\end{array}$ & $\begin{array}{l}6.2578 * * * \\
(5.66)\end{array}$ \\
\hline Constant & $\begin{array}{l}1320.5511^{* * *} \\
(9.16)\end{array}$ & $\begin{array}{l}1910.1564^{* * *} \\
(11.25)\end{array}$ & $\begin{array}{l}956.6548^{* * *} \\
(5.25)\end{array}$ \\
\hline Wald test & $31.54(0.000)$ & $293.77(0.000)$ & $31.62(0.000)$ \\
\hline $\mathrm{AR}(2)$ test & $1.13(0.260)$ & $1.17(0.241)$ & $0.85(0.395)$ \\
\hline Hansen test & $7.79(0.100)$ & $4.79(0.780)$ & $0.77(0.679)$ \\
\hline $\begin{array}{l}\text { DHT for instruments (a) GMM } \\
\text { instruments for levels H excluding } \\
\text { group Dif (null } \mathrm{H}=\text { exogenous) }\end{array}$ & $1.09(0.297)$ & $0.50(0.778)$ & $0.69(0.407)$ \\
\hline $\begin{array}{l}\text { (b) IV (Years, eq (diff)) H excluding } \\
\text { group Dif (null } \mathrm{H}=\text { exogenus) }\end{array}$ & $3.89(0.274)$ & $2.74(0.254)$ & $0.09(0.770)$ \\
\hline Number of Instruments & 9 & 13 & 7 \\
\hline Number of Provinces & 11 & 8 & 10 \\
\hline obs & 220 & 160 & 200 \\
\hline
\end{tabular}

Note: ${ }^{* * *}, * * * *$ represent the significance level of $1 \%, 5 \%$ and $10 \%$, respectively. The coefficients in parentheses of variables and constant terms are $z$ values. The coefficients in parentheses of the Wald test, Hansen test, and AR(2) test are $p$ values.

\section{Results and Discussion}

\subsection{Estimation and Analysis of GTP}

3.1.1. Overall Estimation and Result Analysis

The panel data test of formula (8) is performed, and for the robustness test, three different pollution indicators of $P_{-} C O D, P_{-} C_{2}, P \_p u l$ are used as the independent variables, respectively. Table 3 lists the estimated results, in which the Wald test, AR (2) test, Hansen test, and DHT test all meet the requirements [45].

Human capital has a positive impact on GTP, which shows that the higher the education level, the greater the promotion of GTP. This is because education is the main factor in improving residents' green awareness and labor quality and is also an important prerequisite for cleaner production and management innovation. In addition, there is a significant cross-regional flow of human capital in China, which is also conducive to the dissemination of knowledge and technology, thus promoting GTP. It is consistent with the research of Ma et al. [8].

The coefficient of environmental regulation is significantly negative, and its square term is significantly positive, indicating that environmental regulation has a U-shaped impact on GTP, that is, when environmental regulations are weak, they tend to worsen GTP, and when a certain technological and economic foundation is established, an increase of environmental regulation tends to promote the GTP. The inflection points of the quadratic curves for the three $\ln E_{i t}$ test results are 8.60, 8.94, and 8.98, respectively, which are significantly lower than the mean value of 9.31 in China in 2017, showing that China has passed the point of inflection as a whole, that is, the current environmental regulations are conducive to improving GTP. The current increasing intensity of environmental regulations 
in China has prompted domestic enterprises to develop more clean industries and introduce more advanced green technologies and innovate to achieve stronger competitiveness.

For other control variables, trade openness has a negative impact on GTP. It shows that the status of China's world factories of middle and low manufacturing has not completely changed, trade openness generally tends to strengthen labor-intensive and resourceintensive industries, which is not conducive to GTP. The intersection of trade openness and environmental regulation is significantly positive, indicating that improving environmental regulation under trade openness will promote GTP. Trade openness prompts domestic enterprises to introduce and imitate advanced green technologies, and the increase of environmental regulations strengthens the incentive for GTP. Therefore, the interaction between trade openness and environmental regulation promotes GTP. FDI has a negative impact on the GTP in the second model and failed the test in the first and third models. This may be because FDI in China is not yet environmentally friendly, or the spillover effect of FDI technology is insufficient. The R\&D expenditure has a positive impact on GTP, which shows that R\&D investment is an important material basis to ensure GTP. Environmental pollution $P_{-} C O D, P_{-} C_{2}$, and $P_{-} p u l$ have positive impacts on the GTP, indicating that under the current strong environmental regulations and governments at all levels attaching great importance to environmental protection, severe environmental pollution in a region will stimulate local GTP.

\subsubsection{Regional Estimation and Result Analysis}

To further test whether the comparative advantage of human capital in the CW-regions of China has prompted these regions to choose GTP more, this paper conducts the sysGMM estimation in the three regions. Table 4 lists the estimation results, in which the Wald test, $\mathrm{AR}(2)$ test, Hansen test, and DHT tests all meet the requirements.

Human capital in the three regions has a significant positive effect on GTP, and the coefficients of human capital in the CW-regions are greater than that in the E-region. Local governments have the same environmental protection policies under the unified leadership of the central government, and the three regions all have the driving forces to improve GTP. However, the CW-regions give full play to their comparative advantages in human capital and make use of their strengths and avoid weaknesses in terms of industry selection and technology R\&D direction, so they promote GTP more. Although the main factors of production in the E-region have absolute advantages, the absolute advantage of human capital is relatively small. Therefore, the promotion of GTP by human capital is smaller. Moreover, from China's reform and opening up to the beginning of the 21st century, the cross-regional flow of talent was mainly a one-way flow from the CW-regions to the east. However, after the financial crisis in 2009 ended, the return of talents to work and entrepreneurship in the E-region increased, and the one-way flow of talent turned into a bilateral flow. This has further increased the average years of education of the permanent population in the $\mathrm{CW}$-regions and promoted the dissemination of knowledge and technology, which is conducive to the GTP in the CW-regions.

Environmental regulation is significantly negative, and its square term is significantly positive, indicating that environmental regulations have a U-shaped impact on GTP. The inflection points of the $\ln E_{i t}$ quadratic curve of the three test results in the three regions are $8.9467,8.4962$, and 8.2596, respectively, which are lower than the average values of 9.5781, 9.3552, and 8.8603 in the three regions in 2017, indicating that the eastern, CW-regions have generally passed the inflection point. We found that the inflection points of environmental regulations in the three regions are decreasing progressively. The faster accumulation of human capital and the corresponding industrial and technological choices in the CWregions may lead these regions more quickly to reach the turning point of environmental regulations that promote GTP.

Human capital in the CW-regions has a greater impact on promoting GTP, and the turning point of environmental regulation to promote GTP is lower. Because the gap in GTP rate between the CW-regions and the E-region is significantly smaller than the gap in 
technological progress rate, it can be concluded that the CW-regions in China choose GTP more based on the comparative advantage of human capital. Proposition 1 is proved.

3.2. Estimation and Analysis of the Backwardness Advantage of Green Development in the CW-Regions

To test whether there is a backwardness advantage of green development due to GTP in the CW-regions, the impact of GTP on green GDP is tested according to formula (9). Table 5 lists the estimation results, in which the Wald test, AR(2) test, Hansen test, and DHT test all meet the requirements.

Table 5. Sys-GMM estimation results with per capita green GDP as the dependent variable.

\begin{tabular}{|c|c|c|c|}
\hline Variables & Model (10) & Model (11) & Model (12) \\
\hline $\ln G G D P_{i t-1}$ & $\begin{array}{l}1.0711^{* * *} \\
(79.26)\end{array}$ & $\begin{array}{l}1.1169^{* * *} \\
(60.28)\end{array}$ & $\begin{array}{l}1.1249^{* * *} \\
(55.57)\end{array}$ \\
\hline $\ln W_{i t-1}$ & $\begin{array}{c}-0.0279^{* * *} \\
(-3.23)\end{array}$ & $\begin{aligned}- & 0.0568^{* * *} \\
& (-4.28)\end{aligned}$ & $\begin{aligned}- & 0.0656^{* * *} \\
& (-4.34)\end{aligned}$ \\
\hline$G T P_{i t-1}$ & $\begin{array}{l}0.0010^{* * *} \\
(2.73)\end{array}$ & $\begin{array}{c}0.0013^{* *} \\
(2.13)\end{array}$ & \\
\hline$G T P_{i \mathrm{t}-1}{ }^{*}$ east & & & $\begin{array}{l}0.0019 * * * \\
(2.79)\end{array}$ \\
\hline $\operatorname{GTP}_{i t-1}{ }^{*}$ Backward $_{i-}$ mid & & $\begin{array}{l}0.0022 * * * \\
(3.17)\end{array}$ & $\begin{array}{l}0.0046^{* * *} \\
(4.19)\end{array}$ \\
\hline$G_{\text {TP }-1}{ }^{*}$ Backward $_{i-}$ west & & $\begin{array}{c}0.0020^{*} \\
(1.83)\end{array}$ & $\begin{array}{l}0.0031^{* * *} \\
(2.77)\end{array}$ \\
\hline $\ln H_{i t}$ & $\begin{array}{l}0.0697^{* * *} \\
(3.44)\end{array}$ & $\begin{array}{l}0.0800^{* * *} \\
(3.48)\end{array}$ & $\begin{array}{c}0.1075^{*} \\
(1.70)\end{array}$ \\
\hline $\ln E_{i t}$ & $\begin{array}{l}-0.1338^{* * *} \\
(-13.56)\end{array}$ & $\begin{array}{l}-0.1208^{* * *} \\
(-5.67)\end{array}$ & $\begin{aligned}- & 0.1452 * * * \\
& (-7.51)\end{aligned}$ \\
\hline $\ln K_{i t}$ & $\begin{array}{l}-0.0284^{* * *} \\
(-2.82)\end{array}$ & $\begin{aligned}-0 & 0.0571^{* * *} \\
& (-4.48)\end{aligned}$ & $\begin{aligned}- & 0.0558^{* * *} \\
& (-4.20)\end{aligned}$ \\
\hline $\ln L_{i t}$ & $\begin{array}{l}0.0515^{* * *} \\
(5.79)\end{array}$ & $\begin{array}{l}0.0581 * * * \\
(4.91)\end{array}$ & $\begin{array}{l}0.0640 * * * \\
(5.70)\end{array}$ \\
\hline Constant & $\begin{array}{l}0.6124^{* * *} \\
(5.29)\end{array}$ & $\begin{array}{l}0.5468^{* * *} \\
(4.35)\end{array}$ & $\begin{array}{l}0.6507^{* * *} \\
(4.95)\end{array}$ \\
\hline Wald test & $205,006(0.000)$ & $223,141.21(0.000)$ & $213,607.94(0.000)$ \\
\hline $\mathrm{AR}(2)$ test & $-1.37(0.172)$ & $-1.43(0.152)$ & $-1.41(0.160)$ \\
\hline Hansen test & $22.98(0.816)$ & $18.07(0.204)$ & $20.13(0.126)$ \\
\hline DHT for instruments (a) & & & \\
\hline $\begin{array}{l}\text { GMM instruments for levels } \\
\text { H excluding group Dif } \\
\text { (null H = exogenous) } \\
\text { (b) IV (Years, eq (diff)) H }\end{array}$ & $1.32(0.933)$ & $8.41(0.298)$ & $11.53(0.117)$ \\
\hline $\begin{array}{l}\text { excluding group Dif } \\
\text { (null } \mathrm{H}=\text { exogenus) }\end{array}$ & $2.12(0.347)$ & $4.27(0.118)$ & $2.67(0.264)$ \\
\hline Number of Instruments & 21 & 24 & 24 \\
\hline Number of Provinces & 29 & 29 & 29 \\
\hline obs & 609 & 609 & 609 \\
\hline
\end{tabular}

Note: ${ }^{* *}, * *, *$ represent the significance level of $1 \%, 5 \%$ and $10 \%$, respectively. The coefficients in parentheses of variables and constant terms are $z$ values. The coefficients in parentheses of the Wald test, Hansen test, and AR(2) test are $p$ values.

It is found that GTP significantly promotes the growth of green GDP, and in the second regression result, the coefficients of $G T P_{i t-1} *$ Backward $_{i-}$ mid $_{\text {and }} G T P_{i t-1} *$ Backward $_{i \_}$west are both significantly positive and greater than the coefficient of $G T P_{i t-1}$, indicating that GTP in the CW-regions brings more green GDP growth than the national average level. In the third regression result, the coefficient of $G T P_{i t-1} *$ east is also significantly positive, but it is significantly smaller than the coefficients of $G T P_{i t-1} * B_{1}$ ckward $_{i \_}$mid and $G T P_{i t-1} *$ Backward $_{i \_}$west. It shows that the relatively backward GTP in the CW-regions has a greater effect on promoting green GDP growth than in the E-region. 
In terms of other variables, it is found that the coefficient of wage income is significantly negative, which supports the conditional convergence effect same as $\mathrm{Vu}$ and Asongu [17]. The coefficients of human capital and labor input are significantly positive, which indicates that human factors, especially intellectual factors, are important for green development. The coefficients of material capital and environmental regulation are significantly negative, indicating that China's current development is still relatively extensive, and material capital is less invested in green industries, thus strengthening environmental regulations may be detrimental to the economic growth.

Under environmental regulations, the CW-regions have chosen the direction of GTP more based on their comparative advantages in human capital, and the GTP in the CWregions will further promote the growth of green GDP. Therefore, it can be judged that the CW-regions choose GTP more and enable these regions to obtain the backwardness advantage of green development. Proposition 2 is confirmed.

\subsection{Discussion}

This paper proposes and confirms that the CW-regions make full use of the comparative advantages of human capital to promote the faster development of GTP, and the GTP in these regions further brings about the backwardness advantage of green development. However, more evidence is needed for the theoretical viewpoints presented in this paper. First, more environmental data of China is needed for empirical research, including PM2.5, ecological footprint, etc. Second, it makes the research conclusions limited due to the lack of industrial data. Third, the green GDP calculated in this paper only deducts environmental pollution losses and resource consumption losses, and the calculation method needs further improvement. Fourth, this research is only for China, and it needs empirical support from more countries around the world, especially countries with similar obvious regional economic imbalances, to verify the possibility and universality of the backwardness advantage of green economy. It also needs to be pointed out that the backwardness advantages of green economy in the CW-regions of China proposed in this paper are based on the comparative advantages of human capital in these regions. Therefore, it is necessary to look for international cases with better and relatively balanced educational development, rather than countries with backward education.

\section{Conclusions}

The provinces in the CW-regions in China are relatively underdeveloped and have a strong desire for economic development, but they have also recognized their more fragile ecological environment and thus put forward green development strategies. This paper proposes that the CW-regions in China have the backwardness advantage of green development, which is of great significance for these regions to achieve the dual goals of economic catch-up and environmental protection. The conclusions form a useful supplement to the theory of sustainable development and the theory of backwardness advantage have important theoretical significance for solving the contradiction between economic catch-up and environmental pollution in underdeveloped regions and have important practical significance for the current economic reform of China, as well as important significance for the economic transformation and sustainable development in other developing countries. This paper finds that the CW-regions have comparative advantages in human capital, and the gap in GTP with the E-region is significantly lower than the gap in technological progress. This paper proposes that the comparative advantages of human capital in the CW-regions have prompted these regions to choose GTP more, and the choice of the direction of GTP has enabled these regions to obtain the backwardness advantage of green development. Through the sys-GMM estimation, the panel data of 29 provinces, as well as regional panel data in the mainland of China from 1995 to 2017, were used for empirical research. The results show the following:

Human capital has a positive effect on GTP, and the CW-regions choose GTP based more on the comparative advantages of human capital. Therefore, to promote GTP, the 
government should vigorously develop education to increase the level of human capital. As underdeveloped regions, the CW-regions should not only develop the economy but also protect the environment and develop education more firmly. The CW-regions should develop more knowledge-intensive industries, provide sufficient chances for talent employment and entrepreneurship, and avoid the phenomenon of high consumption of talents.

The CW-regions gain greater green GDP growth from the GTP. That is to say, choosing the direction of GTP in the CW-regions has enabled these regions to obtain the backwardness advantage of green development. To achieve the coordination of economic catch-up and environmental protection through GTP, the CW-regions could increase the support policies for green R\&D and green industries, avoid simply accepting excess industrial transfers from the E-region, and promote the transformation of lucid waters and lush mountains to invaluable assets.

In summary, the theoretical contribution of this paper is that it proved for the first time that there is a backwardness advantage of green development in the CW-regions of China. At the practical level, first, it provides theoretical support for the CW-regions of China to implement policies for green and sustainable development more proactively, so that these regions will pay more attention to education, and be able to avoid highpolluting, low-value-added industries when they are faced with international and eastern industrial transfers. Second, it provides policy reference for other countries with obvious regional economic imbalances like China, including India, Brazil, Indonesia, etc. These countries could implement fairer education policies between regions, as well as proactive environmental and economic policies.

Author Contributions: Conceptualization, H.W. and J.D.; methodology, J.D.; software, J.D.; validation, J.D. and H.W.; formal analysis, H.W.; investigation, J.D.; resources, H.W.; data curation, J.D.; writing — original draft preparation, J.D.; writing—review and editing, H.W.; visualization, J.D.; supervision, H.W.; project administration, H.W.; funding acquisition, H.W. All authors have read and agreed to the published version of the manuscript.

Funding: This research was funded by the Chinese National Social Science Fund Youth Project, grant number 16CJL050.

Institutional Review Board Statement: Not applicable.

Informed Consent Statement: Not applicable.

Data Availability Statement: The datasets used and analyzed in the research are available from the corresponding author on request.

Acknowledgments: The authors are grateful to the editor and the anonymous reviewers for their helpful comments and suggestions, that improved the earlier versions of this paper.

Conflicts of Interest: The authors declare no conflict of interest.

\section{Appendix A}

Table 1. The average growth rate of major economic indicators from 1995 to 2017 (\%).

\begin{tabular}{|c|c|c|c|c|c|c|c|}
\hline Item & $\begin{array}{l}\text { Educational } \\
\text { Expenditure } \\
\text { per Student }\end{array}$ & $\begin{array}{c}\text { The Ratio of the } \\
\text { Population with at } \\
\text { Least Higher Education }\end{array}$ & $\begin{array}{l}\text { Labor Em- } \\
\text { ployment }\end{array}$ & $\begin{array}{c}\text { The Loan Balance } \\
\text { of Financial } \\
\text { Institutions }\end{array}$ & $\begin{array}{c}\text { Per Capita } \\
\text { GDP }\end{array}$ & $\begin{array}{c}\text { Technological } \\
\text { Progress }\end{array}$ & $\begin{array}{l}\text { Green Tech- } \\
\text { nological } \\
\text { Progress }\end{array}$ \\
\hline Eastern region & 12.0482 & 10.4952 & 1.571 & 16.526 & 9.352 & 4.4436 & 5.7655 \\
\hline Central region & 12.4220 & 14.0071 & 1.080 & 14.820 & 10.160 & 2.6733 & 3.8185 \\
\hline Western region & 13.5318 & 11.3515 & 1.188 & 16.183 & 9.988 & 1.8966 & 2.8753 \\
\hline
\end{tabular}

Note: The above data are calculated based on the relevant statistical yearbooks of the National Bureau of Statistics and the relevant statistical yearbooks of various provinces and regions. The price of educational expenditure per capita and per capita GDP is based on 1995 . The technological progress rate is calculated by the DDF and fixed reference Malmquist model and the cumulative multiplication method of Yuan [52]. 


\section{References}

1. Gerschenkron, A. Economic Backwardness in Historical perspective: A Book of Essays; Belknap Press of Harvard University Press: Cambridge, UK, 1962.

2. Abramovitz, M. Catching up, forging ahead, and falling behind. J. Econ. Hist. 1986, 46, 385-406. [CrossRef]

3. Brezis, E.S.; Krugman, P.R.; Tsiddon, D. Leapfrogging in International Competition: A Theory of Cycles in National Technological Leadership. Am. Econ. Rev. 1993, 83, 1211-1219.

4. Sachs, J.; Woo, W.T.; Yang, X. Economic Reforms and Constitutional Transition. Ann. Econ. Financ. $2000,2,435-491$.

5. Guo, X.B. Backwardness Advantage and Leap Forward Development. Guang Ming Daily. 2004. Available online: https: //global.cnki.net/index/Marketing/News/eng/voiceofcnki/3.html (accessed on 1 July 2021).

6. Ma, S.Q.; Dai, J.; Wen, H.D. The influence of trade openness on the level of human capital in China: On the basis of environmental regulation. J. Clean. Prod. 2019, 225, 340-349. [CrossRef]

7. Acemoglu, D. Directed Technical Change. Rev. Econ. Stud. 2002, 69, 781-809. [CrossRef]

8. Ma, S.Q.; Dai, J.; Wen, H.D. Trade Openness, Environmental Regulation and Green Technology Progress-Spatial Econometric Analysis Based on Provincial Data in China. J. Int. Trade 2019, 10, 132-145.

9. Chung, Y.H.; Färe, R.; Grosskopf, S. Productivity and Undesirable Outputs: A Directional Distance Function Approach. J. Environ. Manag. 1997, 3, 229-240. [CrossRef]

10. Jing, W.M.; Zhang, L. Environmental regulation, opening up and green technological progress of Chinese industry. Econ. Res. 2014, 9, 34-47.

11. Howitt, P. Endogenous growth and cross-country income differences. Am. Econ. Rev. 2000, 90, 829-846. [CrossRef]

12. Lin, J. China's Rise and Opportunity for Structural Transformation in Africa. J. Afr. Econ. 2018, 27, i15-i28. [CrossRef]

13. Howitt, P.; Mayer-Foulkes, D. R\&D, implementation and stagnation: A Schumpeterian theory of convergence clubs. J. Money Credit. Bank. 2005, 37, 147-177.

14. Lin, Y.F.; Zhang, P.F. The advantage of Latter Comers, Technology Imports and Economic Growth of Developing Countries. China Econ. Q. 2005, 10, 53-74.

15. Landesmann, M.A.; Stehrer, R. Industrial specialization, catching-up and labour market dynamics. Metroeconomica 2000, 51, 67-101. [CrossRef]

16. Utku-İsmihan, F.M. Knowledge, technological convergence and economic growth: A dynamic panel data analysis of Middle East and North Africa and Latin America. Qual. Quant. 2019, 53, 713-733. [CrossRef]

17. Vu, K.M.; Asongu, S. Backwardness advantage and economic growth in the information age: A cross-country empirical study. Technol. Forecast. Soc. Chang. 2020, 159, 120197. [CrossRef]

18. Gosens, J.; Gilmanova, A.; Lilliestam, J. Windows of opportunity for catching up in formative clean-tech sectors and the rise of China in concentrated solar power. Environ. Innov. Soc. Transit. 2021, 39, 86-106. [CrossRef]

19. Chen, T.; Lu, H.; Chen, R.; Wu, L. The Impact of Marketization on Sustainable Economic Growth—Evidence from West China. Sustainability 2021, 13, 3745. [CrossRef]

20. Fagerberg, J. Convergence or divergence? The impact of technology on "why growth rates differ". J. Evol. Econ. 1995, 5, 269-284. [CrossRef]

21. Forbes, N.; Wield, D. Managing R\&D in technology-followers. Res. Policy 2000, 29, 1095-1109.

22. Harada, T. Advantages of backwardness and forwardness with shifting comparative advantage. Res. Econ. 2012, 66, 72-81. [CrossRef]

23. Zabala-Iturriagagoitia, J.M.; Aparicio, J.; Ortiz, L.; Carayannis, E.G.; Grigoroudis, E. The productivity of national innovation systems in Europe: Catching up or falling behind? Technovation 2021, 102, 102215. [CrossRef]

24. Rho, S.; Lee, K.; Kim, S.H. Limited catch-up in China's semiconductor industry: A sectoral innovation system perspective. Millenn. Asia 2015, 6, 147-175. [CrossRef]

25. Minaee, M.; Elahi, S.; Majidpour, M.; Manteghi, M. Lessons learned from an unsuccessful "catching-up" in the automobile industry of Iran. Technol. Soc. 2021, 66, 101595. [CrossRef]

26. Lantz, V.; Feng, Q. Assessing income, population, and technology impacts on $\mathrm{CO}_{2}$ emissions in Canada: Where's the EKC? Ecol. Econ. 2006, 57, 229-238. [CrossRef]

27. Feng, K.; Hubacek, K.; Guan, D. Lifestyles, technology and $\mathrm{CO}_{2}$ emissions in China: A regional comparative analysis. Ecol. Econ. 2009, 69, 145-154. [CrossRef]

28. International Energy Agency (IEA). World Energy Outlook Special Report 2013: Redrawing the Energy Climate Map; IEA Publications: Paris, France, 2013.

29. International Energy Agency (IEA). Energy Technology Perspectives 2015: Mobilising Innovation to Accelerate Climate Action; IEA Publications: Paris, France, 2015.

30. Jin, L.; Duan, K.; Shi, C.; Ju, X. The impact of technological progress in the energy sector on carbon emissions: An empirical analysis from China. Int. J. Environ. Res. Public Health 2017, 14, 1505. [CrossRef] [PubMed]

31. Dong, F.; Yu, B.; Hadachin, T.; Dai, Y.; Wang, Y.; Zhang, S.; Long, R. Drivers of carbon emission intensity change in China. Resour. Conserv. Recycl. 2018, 129, 187-201. [CrossRef]

32. Bergamini, E.; Zachmann, G. Exploring EU's Regional Potential in Low-Carbon Technologies. Sustainability 2021, 13, 32. [CrossRef]

33. Nikzad, R.; Sedigh, G. Greenhouse gas emissions and green technologies in Canada. Environ. Dev. 2017, 24, 99-108. [CrossRef] 
34. Sun, Y.; Li, M.; Zhang, M.; Khan, H.; Li, J.; Li, Z.; Sun, H.; Zhu, Y.; Anaba, O. A study on China's economic growth, green energy technology, and carbon emissions based on the Kuznets curve (EKC). Environ. Sci. Pollut. Res. 2021, 28, 7200-7211. [CrossRef] [PubMed]

35. Weina, D.; Gilli, M.; Mazzanti, M.; Nicolli, F. Green inventions and greenhouse gas emission dynamics: A close examination of provincial Italian data. Environ. Econ. Policy Stud. 2016, 18, 247-263. [CrossRef]

36. Su, H.N.; Moaniba, I.M. Does innovation respond to climate change? Empirical evidence from patents and greenhouse gas emissions. Technol. Forecast. Soc. Chang. 2017, 122, 49-62. [CrossRef]

37. Gu, W.; Chu, Z.; Wang, C. How do different types of energy technological progress affect regional carbon intensity? A spatial panel approach. Environ. Sci. Pollut. Res. 2020, 27, 44494-44509. [CrossRef]

38. Paramati, S.R.; Mo, D.; Huang, R.X. The role of financial deepening and green technology on carbon emissions: Evidence from major OECD economies. Financ. Res. Lett. 2020, 7, 101794. [CrossRef]

39. Wang, Z.; Yang, Z.; Zhang, Y.; Yin, J. Energy technology patents- $\mathrm{CO}_{2}$ emissions nexus: An empirical analysis from China. Energy Policy 2012, 42, 248-260. [CrossRef]

40. Braungardt, S.; Elsland, R.; Eichhammer, W. The environmental impact of eco-innovations: The case of EU residential electricity use. Environ. Econ. Policy Stud. 2016, 18, 213-228. [CrossRef]

41. Popp, D. The Role of Technological Change in Green Growth; NBER Working Paper No. w18506; National Bureau of Economic Research: Cambridge, CA, USA, 2012.

42. Acemoglu, D.; Gancia, G.; Zilibotti, F. Competing engines of growth: Innovation and standardization. J. Econ. Theory 2012, 147, 570-601. [CrossRef]

43. Du, K.R.; Li, P.Z.; Yan, Z.M. Do green technology innovations contribute to carbon dioxide emission reduction? Empirical evidence from patent data. Technol. Forecast. Soc. Chang. 2019, 146, 297-303. [CrossRef]

44. Copeland, B.R.; Taylor, M.S. Trade and the Environment: Theory and Environment; Princeton University Publishing House: Princeton, NJ, USA, 2003.

45. Wen, H.D.; Dai, J. The Change of Sources of Growth and Sustainable Development in China: Based on the Extended EKC Explanation. Sustainability 2021, 13, 2803. [CrossRef]

46. Rybczynski, T.M. Factor Endowment and Relative Commodity Prices. Econometrica 1955, 22, 336-341. [CrossRef]

47. Wen, H.D.; Tan, J.R. Low-Carbon Strategy with Chinese SMEs. Energy Procedia 2011, 5, 613-618.

48. Zhang, C.; He, W.D.; Hao, R. Analysis of environmental regulation and total factor energy efficiency. Curr. Sci. 2016, 110, 1958-1968. [CrossRef]

49. Eicher, T.S.; Schreiber, T. Structural policies and growth: Time series evidence from a natural experiment. J. Dev. Econ. 2010, 91, 169-179. [CrossRef]

50. Tan, J.R.; Wen, H.D. Analysis on the stage of environmental pollution in economy in Yangtze River Delta. Financ. Trade Econ. 2010, 5, 123-129.

51. Wen, H.D. Hangzhou's Green GDP Accounting Index System and Its Applied Research. J. Tech. Econ. Manag. 2011, 2, 110-113.

52. Yuan, Y.J.; Xie, R.R. FDI, Environmental Regulation and Green Total Factor Productivity Growth of China's Industry: An Empirical Study Based on Luenberger Index. J. Int. Trade 2015, 8, 84-93.

53. Wen, H.D.; Dai, J. Trade openness, environmental regulation, and human capital in China: Based on ARDL cointegration and Granger causality analysis. Environ Sci. Pollut. Res. 2020, 27, 1789-1799. [CrossRef]

54. Li, J.; Tan, Q.M.; Bai, J.H. Spatial Econometric Analysis of Regional Innovation Production in China-An Empirical Study Based on Static and Dynamic Spatial Panel Models. Manag. World 2010, 7, 43-65.

55. Chen, S.Y. Energy Consumption, $\mathrm{CO}_{2}$ Emission and sustainable development in Chinese industry. Econ. Res. J. 2009, 4, 41-55.

56. Zhang, J.; Wu, G.Y.; Zhang, J.P. The estimation of China's provincial capital stock: 1952-2000. Econ. Res. J. 2004, 10, 35-44.

57. Arellano, M.; Bond, S. Some tests of specification for panel data: Monte Carlo evidence and an application to employment equations. Rev. Econ. Stud. 1991, 58, 277-297. [CrossRef]

58. Arellano, M.; Bover, O. Another look at the instrumental variable estimation of error components models. J. Econom. 1995, 68, 29-52. [CrossRef]

59. Blundell, R.; Bond, S. Initial Conditions and Moment Restrictions in Dynamic Panel Data Models. J. Econom. 1998, 87, 115-143. [CrossRef]

60. Asongu, S.; Nwachukwu, J.C. Foreign aid and governance in Africa. Int. Rev. Appl. Econ. 2016, 30, 69-88. [CrossRef]

61. Chen, Q. Application of Stata in Econometrics; Higher Education Press: Beijing, China, 2016.

62. Wooldridge, J.M. Introductory Econometrics: A Modern Approach, 5th ed.; South-Western Cengage Learning: Mason, OH, USA, 2012. 